\title{
Subversive Capabilities
}

At a recent event staged at the Architecture Foundation in London the critic William Curtis and five distinguished colleagues galvanised each other in a move to resist what they saw as the increasingly turgid, market-led demands of commercial architectural publishing. In Curtis's opinion the critic's role is to 'reveal the mechanisms' of power - something, it is evident, that he and his fellow critics are largely failing to do. Hearing these thoughts made us reflect on the independent status of arq, its subversive capability, its singular position in the market and its potential to offer different interpretations of architecture.

The 'mechanisms of power' play a central role in Marwan Ghandour's readings (pp37-49) of a series of twentieth-century master plans for Balbaak in the Lebanon. The city's extraordinary temple complex has been co-opted and recast by successive ruling authorities to further their own ends, and working with students at the American University in Beirut, Ghandour suggests another ordering of the city, based on sensitive engagement and intense observation.

Curtis made a further plea for the 'delicate, intense reading' of buildings that are subtle and emanate from architectural concerns rather than those of status or fashion - buildings, we would suggest, like the Urray House discussed by John Brennan in his paper on Scottish Highland architecture (pp12-23). Ostensibly simple in form and detail, it engages in quiet but eloquent conversation with both its owners and the exposed rural setting.

An intense reading of Le Corbusier's studio residences, the Atelier Ozenfant and his own penthouse at 24 Nungesser et Coli is offered by Todd Willmert (pp57-78). In a groundbreaking analysis, a potentially mundane issue of building servicing - the provision of heat - is tied into the overarching narrative of the architecture. Given that Louis Kahn constantly referred back to Le Corbusier, it is perhaps unsurprising that a parallel strand of thought is revealed by Steven Fleming in his analysis of daylight in Kahn's work (pp25-36). Although apparently more instinctual in his theorising, Kahn also, Fleming argues, sought meaning in Platonic thought when asked to design a religious building.

As the divorce between conceptual idea and constructional technique grows ever wider in mainstream practice, should it be our remit to reassert the act of detailing as an art? The etymology is revealing: derived from the latin artem, art refers to skill or craft. Such simple definitions can hardly describe the overlapping fields of activity that constitute architecture, yet in our increasingly bureaucratic world we are forced to define ourselves at every stage. Products of art or craft can be ascribed different levels of VAT; Health and Safety legislation is variously interpreted; and expected standards of workmanship and utility differ. Confronted by a Building Control officer, thoughts of artistry have a tendency to evaporate - all the more reason to applaud those who hold fast to their aspirations.

THE EDITORS 


\section{architectural research quarterly}

\section{Subscribe now for 2007}

Innovative in conception, unique in breadth

and generously illustrated, this pace-setting quarterly publication from Cambridge

University Press links, on a global scale, the worlds of architectural practice and research. arq regularly includes extensive peer-reviewed sections on design, history, theory, construction, environmental design, information technology and practice - as well as structures, urbanism and documents. These are supplemented by letters, reports, reviews, a directory of specialist research centers and consultancies and an annual index. Each issue opens with a leader and closes with insight, a personal end-piece. In its three year history, arq has published work from all over the world: from Chile to Sweden and from Japan to the Netherlands - with a strong representation from the United Kingdom and United States. arq, like architecture itself, is all-embracing and written by and for both practitioners and academics. It provides an outlet for all those who wish to disseminate their work to an international audience.
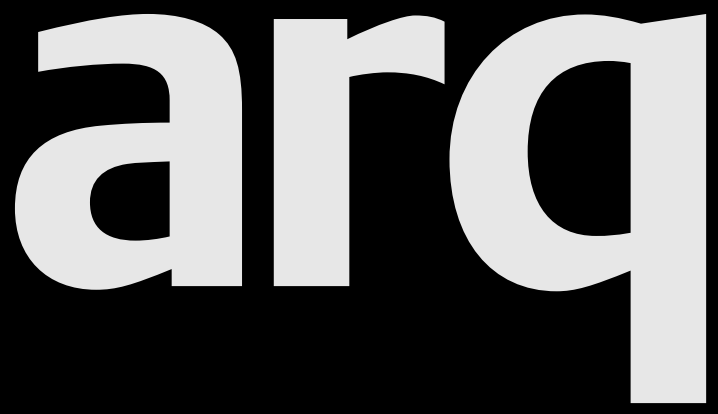

Please enter my subscription to

arq: architectural research quarterly, volume 11, 2007

$\square \in 156 / \$ 252$ institutions print and electronic

$E_{30} / \$ 50$ students print only

$£ 42 / \$ 64$ individuals print only

EU residents only. VAT may be payable at your local rate if not registered.

Our VAT registration number: GB 214141614 If registered, your VAT registration no:

Total subscription payment $€ / \$$ EU residents only, if not registered add VAT at appropriate rate ${ }^{E}$

Canadian residents, add $7 \%$ GST \$

Total $\mathbf{E} / \$$

Name

Address

Payment enclosed

Cheque in sterling or US dollars (payable to Cambridge University Press)

Credit Card - VISA | MasterCard | American Express (delete where applicable)

Card no

Expiry date

Signature

Photocopy this page and send your order to:

Journals Customer Services, Cambridge University Press, The Edinburgh Building, Cambridge, CB2 8RU, UK

T $+44(0) 1223326070$

F +44 (o) 1223315052

E journals@cambridge.org

or in USA, Canada and Mexico send to:

Cambridge University Press, 32 Avenue of the

Americas, New York NY 10013-2473, USA

T (914) 9379600

F (914) 9374712

E journals_subscriptions@cup.org 